\title{
Stress influenced increase in phenolic content and radical scavenging capacity of Rhodotorula glutinis CCY 20-2-26
}

\author{
Raj Kumar Salar • Milan Certik • Vlasta Brezova • \\ Marta Brlejova · Vladimira Hanusova • \\ Emília Breierová
}

Received: 28 March 2012/Accepted: 5 May 2012/Published online: 30 May 2012

(C) The Author(s) 2012. This article is published with open access at Springerlink.com

\begin{abstract}
Rhodotorula glutinis CCY 20-2-26 when grown under controlled stress of either $\mathrm{NaCl}(1-5 \%)$ or $\mathrm{H}_{2} \mathrm{O}_{2}$ $(1-5 \mathrm{mM})$ on basal media exhibited a twofold increase in its total phenolic contents. The radical scavenging capacities (RSCs) as determined by ABTS test were found to be highest in $4 \mathrm{mM} \mathrm{H}_{2} \mathrm{O}_{2}\left(1.44 \mathrm{mM} \mathrm{TEAC} \mathrm{mg}^{-1}\right)$ and $4 \% \mathrm{NaCl}$ (1.13 mM TEAC $\left.\mathrm{mg}^{-1}\right)$ as compared to control samples $\left(0.41 \mathrm{mM}\right.$ TEAC $\left.\mathrm{mg}^{-1}\right)$. Similarly, the RSCs as determined by DPPH test were also highest in $4 \% \mathrm{NaCl}(1.83$ $\mathrm{mM}$ TEAC $\left.\mathrm{mg}^{-1}\right)$ and $4 \mathrm{mMH}_{2} \mathrm{O}_{2}\left(1.78 \mathrm{mM} \mathrm{TEAC} \mathrm{mg}^{-1}\right)$ compared to control $\left(0.48\right.$ TEAC $\left.\mathrm{mg}^{-1}\right)$. The relative RSCs from EPR spin-trapping assay for $\mathrm{H}_{2} \mathrm{O}_{2}$-stressed cultures were highest in $1 \mathrm{mM} \mathrm{H}_{2} \mathrm{O}_{2}\left(56.1 \mu \mathrm{M}\right.$ TEAC $\left.\mathrm{g}^{-1}\right)$ whereas in $\mathrm{NaCl}$-stressed cultures it was highest in $5 \% \mathrm{NaCl}$ (44.6 $\mu \mathrm{M}$ TEAC $\left.\mathrm{g}^{-1}\right)$ as compared to control $(30.9 \mu \mathrm{M}$ TEAC $\mathrm{g}^{-1}$ ). Five phenolic compounds (gallic acid, benzoic acid, catechin, caffeic acid and ferulic acid) were detected for the first time in R. glutinis CCY 20-2-26.
\end{abstract}

Keywords Rhodotorula $\cdot$ Phenolics $\cdot$ Radical scavenging capacity $\cdot$ HPLC $\cdot$ EPR/spin trapping

R. K. Salar ( $\square)$

Department of Biotechnology, Chaudhary Devi

Lal University, Sirsa 125 055, India

e-mail: rajsalar@rediffmail.com

M. Certik · V. Brezova $\cdot$ M. Brlejova $\cdot$ V. Hanusova Faculty of Chemical and Food Technology,

Slovak University of Technology, Radlinskeho 9,

81237 Bratislava, Slovak Republic

E. Breierová

Institute of Chemistry, Slovak Academy of Sciences,

Dúbravská cesta 9, 84538 Bratislava, Slovak Republic

$\begin{array}{ll}\text { Abbreviations } \\ \text { ABTS } & \begin{array}{l}2,2^{\prime} \text {-Azino-bis(3-ethylbenzothiazoline-6- } \\ \text { sulfonic acid) diammonium salt }\end{array} \\ \text { DCW } & \begin{array}{l}\text { Dry cell weight } \\ \text { DMPO }\end{array} \\ \text { 5,5-Dimethyl-1-pyrroline } N \text {-oxide } \\ \text { DMSO } & \text { Dimethylsulfoxide } \\ \text { DPPH } & \text { 1,1-Diphenyl-2-picrylhydrazyl } \\ \text { EPR } & \text { Electron paramagnetic resonance } \\ \text { FC } & \text { Folin and Ciocalteu's phenol reagent } \\ \text { GAE } & \text { Gallic acid equivalent } \\ R & \text { Correlation coefficient } \\ \text { RRSC } & \text { Relative radical scavenging capacity } \\ \text { RSC } & \text { Radical scavenging capacity } \\ \text { SW } & \text { Magnetic field sweep } \\ \text { TEAC } & \text { Trolox equivalent antioxidant capacity } \\ \text { TPC } & \text { Total phenolic content } \\ \text { UV-Vis } & \text { Ultraviolet/visible }\end{array}$

\section{Introduction}

Stress in biological tissues is known to bring about a biochemical response involving an increase in the levels of various antioxidant compounds or in the activity of enzymes responsible for the regeneration of antioxidant metabolites (Ramotar et al. 1998). Earlier, several studies were carried out to show that yeast species produce increased levels of carotenoids when they are grown under unfavourable conditions (Certik and Breierova 2002; Marova et al. 2004). Although, yeast is a non-photosynthetic microorganism, there are yeasts that can biosynthesize carotenoids and phenolic compounds in the cell. Carotenoids and phenolic compounds combat various types 
of cancer and other diseases because of their free radical scavenging and/or provitamin A (carotene) potential (Bhosale and Gadre 2001). Free radicals are known to be a product of normal metabolism. These are also involved in organism's vital activities including phagocytosis, regulation of cell proliferation, intracellular signalling and synthesis of biologically active compounds (Halliwell 1989; Miquel and Romano-Bosca 2004).

Phenolic compounds from plant kingdom are well documented for their antioxidant properties and health promoting benefits. However, little attention has been paid to the phenolic compounds evaluation in yeasts (Rizzo et al. 2006). In the recent past, both eukaryotic and aerobic prokaryotic organisms have been developed with an overall antioxidant defence system for mitigating the damaging effects of free radicals (Kullisaar 2002; Daeschel 2004; Jaehrig et al. 2008; Chen et al. 2010). Nevertheless, all aerobic organisms including humans have antioxidant defences that protect against oxidative damage and repair damaged molecules. However, the natural antioxidant mechanisms can be inadequate, the supply of antioxidants through dietary ingredients is of great interest for the food industry (Scalbert and Williamson 2000; Greenwald et al. 2001; Chen et al. 2010).

Although, the yeasts have received extensive concern on using them as starter cultures for development of new products (Wouters et al. 2002) and potential probiotics (Psomas et al. 2001, 2003; Kumura et al. 2004), studies related to radical scavenging capacities (RSCs) of yeasts are scanty (Rapta et al. 2005). In order to survive in adverse environment, microorganisms have developed efficient adaptation mechanisms to tide over undesirable stress by activated synthesis of biomolecules (Estruch 2000; Certik and Breierova 2002). Thus, studies related to exogenous stress and scavenging property could explain in part the mechanism of protection against harmful effects of the environment. The purpose of the present investigation was to determine total phenolic compounds of Rhodotorula glutinis CCY 20-2-26 grown under controlled stress of $\mathrm{NaCl}$ or $\mathrm{H}_{2} \mathrm{O}_{2}$ including its intact cells and cell free extracts. Radical scavenging capacity of its extracts modulated by $\mathrm{NaCl}$ or $\mathrm{H}_{2} \mathrm{O}_{2}$ was evaluated by EPR spin-trapping technique, DPPH and ABTS assays which may provide evidence for exploring novel products with antioxidant activity. Further, phenolic compounds were identified using HPLC.

\section{Materials and methods}

Microorganism and culture conditions

Rhodotorula glutinis CCY 20-2-26 was obtained from Culture Collection of Yeasts (CCY, Institute of Chemistry, Slovak Academy of Sciences, Bratislava, Slovak Republic) and maintained on agar slants at $4{ }^{\circ} \mathrm{C}$. It was cultivated on basal medium consisting of $\left(\mathrm{g} \mathrm{L}^{-1}\right)$ : yeast extract, 5; glucose, 20; $\left(\mathrm{NH}_{4}\right)_{2} \mathrm{SO}_{4}, 10 ; \mathrm{KH}_{2} \mathrm{PO}_{4}, 1 ; \mathrm{K}_{2} \mathrm{HPO}_{4} \cdot 3 \mathrm{H}_{2} \mathrm{O}$, $0.2 ; \mathrm{NaCl}, 0.1 ; \mathrm{CaCl}_{2}, 0.1 ; \mathrm{MgSO}_{4} \cdot 7 \mathrm{H}_{2} \mathrm{O}, 0.5$; and $0.25 \mathrm{~mL}$ of microelement solution $\left[\left(\mathrm{mg} \mathrm{L}^{-1}\right): \mathrm{H}_{3} \mathrm{BO}_{4}, \quad 1.25\right.$; $\mathrm{CuSO}_{4} \cdot 5 \mathrm{H}_{2} \mathrm{O}, 0.1 ; \mathrm{KI}, 0.25 ; \mathrm{MnSO}_{4} \cdot 5 \mathrm{H}_{2} \mathrm{O}, 1 ; \mathrm{FeCl}_{3} \cdot 6 \mathrm{H}_{2} \mathrm{O}$, 0.5; $\left(\mathrm{NH}_{4}\right)_{2} \mathrm{Mo}_{7} \mathrm{O}_{24} \cdot 4 \mathrm{H}_{2} \mathrm{O}, 0.5$; and $\mathrm{ZnSO}_{4} \cdot 7 \mathrm{H}_{2} \mathrm{O}$, 1]. For the present study, $R$. glutinis was grown under non-lethal and maximally tolerated concentration of either $\mathrm{NaCl}$ (1-5 \%) or $\mathrm{H}_{2} \mathrm{O}_{2}(1-5 \mathrm{mM})$. The inoculum $(10 \% \mathrm{v} / \mathrm{v})$ consisted of 48-h-old cells of $R$. glutinis grown in the above basal media. The cultures were cultivated in $500 \mathrm{~mL}$ Erlenmeyer flasks containing $150 \mathrm{~mL}$ of cultivation medium on a rotary shaker $(140 \mathrm{rpm})$ at $28^{\circ} \mathrm{C}$ to early stationary growth phase. Cells were harvested by centrifugation at 3,000 rpm and washed thrice with distilled water and stored at $-20{ }^{\circ} \mathrm{C}$ until further analysis.

\section{Extraction of phenolic compounds}

The extraction of phenolic compounds was performed directly on the microbial biomass. Dry yeast biomass (DCW-dry cell weight) was prepared gravimetrically. For preparing methanol extracts, $200 \mathrm{mg}$ of DCW was suspended in $20 \mathrm{~mL}$ of methanol in $100-\mathrm{mL}$ conical flasks. The samples were shaken for $10 \mathrm{~min}$ and then centrifuged at 5,000 rpm for $10 \mathrm{~min}$. The supernatants were collected. The DMSO extracts were prepared using yeast biomass with $1 \mathrm{~mL}$ DMSO (Merck, Germany) at $60{ }^{\circ} \mathrm{C}$ for $60 \mathrm{~min}$ in 2-mL Eppendorf tubes and then centrifuged at $5,000 \mathrm{rpm}$ for $10 \mathrm{~min}$. The extracts obtained were filtered through membrane filters $(0.22 \mu \mathrm{m})$. All extracts were stored at $-20{ }^{\circ} \mathrm{C}$ until further analysis of total phenolic content and $\mathrm{RSC}$.

Total polyphenolic content determination

Total polyphenol contents were determined on the biomass of harvested cells (herein after called "cells") and DMSO and methanol extracts (herein after called "extracts") of $R$. glutinis using Folin-Ciocalteu (FC) reagent following $\mathrm{Yu}$ et al. (2004) and Commission Regulation (EEC) No. 2676/90 (1990) with slight modifications. Briefly, $10 \mathrm{mg}$ of yeast biomass was taken and suspended in $10 \mathrm{~mL}$ volumetric flask with $0.5 \mathrm{~mL}$ of distilled water. Then $0.5 \mathrm{~mL}$ of FC reagent (Merck) and $1.5 \mathrm{~mL}$ of aqueous sodium carbonate anhydrous solution $20 \%(\mathrm{w} / \mathrm{v})$ was added. The flask was filled with distilled water to volume and the suspension was poured off into a centrifuge tube. After $120 \mathrm{~min}$, the suspension was centrifuged at 4,000 rpm for $5 \mathrm{~min}$. The absorbance was read at $765 \mathrm{~nm}$, subtracting the value of a control solution consisting of distilled water instead of biomass. For determination of total polyphenol 
content in DMSO and methanol extracts, $100 \mu \mathrm{L}$ of extracts were taken instead of yeast biomass. The amount of total polyphenol was calculated as gallic acid equivalents (GAE) from the standard calibration curve of gallic acid (Sigma-Aldrich) and expressed as milligram gallic acid equivalents per gram of yeast. It should be noted that no significant polyphenolic activity was observed in methanol extracts and thus, only DMSO extracts were used for analysis of RSC.

\section{DPPH radical scavenging assay}

The free RSC of different fractions was measured by the DPPH (1,1-diphenyl-2-picrylhydrazyl) scavenging method according to Yen and Chen (1995) with some modifications. Briefly, $200 \mu \mathrm{L}$ of DMSO extract was taken in spectrophotometric cell and then $3 \mathrm{~mL}$ of $100 \mu \mathrm{M} \mathrm{DPPH}$ (Sigma-Aldrich) (4 mg DPPH in $100 \mathrm{~mL}$ methanol) was added. In the reference sample, $200 \mu \mathrm{l}$ of DMSO was used instead of extracts. The changes in absorbance at $519 \mathrm{~nm}$ in minute 10 relative to the reference sample were recorded using a Implen NanoPhotometer 1890 (version, 7122 V2.0.0). The DPPH RSCs were expressed as trolox equivalent antioxidant capacity (TEAC) in $\mu \mathrm{mol} \mathrm{g}^{-1}$ of yeast biomass.

$\mathrm{ABTS}^{\bullet+}$ radical cation depolarization assay

Antioxidant activity was measured using a modified method of Re et al. (1999) and Arts et al. (2004). 2,2'-Azino-bis (3-ethylbenzothiazoline-6-sulfonate) (ABTS, Sigma) was used for production of the corresponding radical cation $\left(\mathrm{ABTS}^{\bullet+}\right.$ ) by dissolving $17.2 \mathrm{mg}$ ABTS and $3.3 \mathrm{mg}$ $\mathrm{K}_{2} \mathrm{~S}_{2} \mathrm{O}_{8}$ (Aldrich) in 5-mL distilled water, and the resulting solution was left to stand for $16 \mathrm{~h}$ in dark at room temperature. A stock solution of $\mathrm{ABTS}^{\bullet+}$ was prepared by mixing $1 \mathrm{~mL}$ of this reaction mixture with $60-\mathrm{mL}$ water. The concentration of $\mathrm{ABTS}^{\bullet+}$ was determined by UV-Vis spectroscopy using the characteristic value of molar absorption coefficient at $732 \mathrm{~nm}, 1.5 \times 10^{4} \mathrm{~mol}^{-1} \mathrm{~L} \mathrm{~cm}^{-1}$. After rigorously mixing $2.3-\mathrm{mL} \mathrm{ABTS}^{\bullet+}$ solution with $200 \mu \mathrm{L}$ of DMSO extracts, the UV-Vis spectra were taken in $0.5 \mathrm{~s}$ intervals for $10 \mathrm{~min}$ using UV-3600 UV-Vis spectrophotometer (Shimadzu, Japan, 1-cm square quartz cell). UVVis spectrum of initial $\mathrm{ABTS}^{\bullet+}$ solution measured against distilled water was taken as a reference spectrum. The difference in the absorbance in 10th min at $732 \mathrm{~nm}$ relative to reference spectrum was used to calculate the antioxidant activity. The ability of samples to eliminate $\operatorname{ABTS}^{\bullet+}$ is expressed using 6-hydroxy-2,5,7,8-tetramethylchroman-2carboxylic acid (trolox, Aldrich) as reference antioxidant and the results were expressed as TEAC in $\mu \mathrm{mol} \mathrm{g}^{-1}$ of yeast biomass (DCW).
EPR spin-trapping technique

The thermal decomposition of potassium persulfate $\left(\mathrm{K}_{2} \mathrm{~S}_{2} \mathrm{O}_{8}\right)$ in DMSO at $333 \mathrm{~K}$ was used as a source of reactive radicals. To measure the RSC of yeast extracts, the EPR spin-trapping technique (Rapta et al. 2005) was used, employing 5,5-dimethyl-1-pyrroline $N$-oxide (DMPO, Sigma-Aldrich) as a spin trap. Sulfate radical anions $\left(\mathrm{SO}_{4}^{--}\right)$generated upon thermal decomposition of $\mathrm{K}_{2} \mathrm{~S}_{2} \mathrm{O}_{8}$ represent reactive species with high reduction potential, capable to react with a variety of organic compounds (Wardman 1989). In DMSO solvent these paramagnetic species are added to the double bond of DMPO spintrapping agent producing the corresponding spin adducts (Zalibera et al. 2009). All EPR measurements were carried out in a 4-mm flat quartz cell in a Bruker TE 102 (ER 4102 ST) cavity using the EMX EPR spectrometer (Bruker, Rheinstetten, Germany) working in the X-band. The ER 4111 VT temperature unit (Bruker, Germany) was used for temperature regulation. The reaction mixture consisted of $100 \mu \mathrm{L}$ of DMSO extracts (pure DMSO in reference), $100 \mu \mathrm{L}$ DMSO, $25 \mu \mathrm{L}$ of $0.2 \mathrm{M}$ DMPO dissolved in DMSO and $25 \mu \mathrm{L}$ of $0.01 \mathrm{M} \mathrm{K}_{2} \mathrm{~S}_{2} \mathrm{O}_{8}$ (DMSO). A time course of EPR spectra of the DMPO spin adducts was recorded in 66-s intervals for $22 \mathrm{~min}$ at $333 \mathrm{~K}$ (each spectrum represents an accumulation of three scans). The integral EPR intensity (double integral) found after $22 \mathrm{~min}$ of thermal treatment for the sample solution was compared with the reference measurement. The difference between the integral EPR intensities of the reference and the samples in 22nd min characterises the amount of radicals scavenged by the various components present in the sample acting as radical scavengers. The RSC values were calculated as a percentage of scavenged radicals relative to the reference sample (DMSO). These values were recalculated to TEAC using calibration curve measured analogously for trolox solutions in $\mathrm{K}_{2} \mathrm{~S}_{2} \mathrm{O}_{8} / \mathrm{DMPO} / \mathrm{DMSO}$ systems, and so obtained radical scavenging characteristics of investigated samples were evaluated in $\mu \mathrm{mol}$ of trolox $/ 1 \mathrm{~g}$ of extract.

\section{HPLC analysis of phenolic compounds}

Phenolic compounds were analysed by HPLC on an Agilent 1100 series HPLC unit with computer-controlled software and system controller. Mobile phase consisted of acetonitrile (A) and water/acetic acid ( $\mathrm{pH} 2.8)$ (B). Linear gradient from 5 to $100 \% \mathbf{A}$ in $35 \mathrm{~min}$ and flow rate

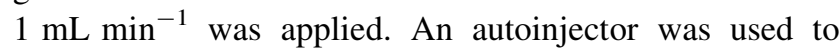
inject $10 \mu \mathrm{L}$ of extracts or standards into the HPLC system. Absorbance data were recorded at $272 \mathrm{~nm}$ over a period of 35 min. Phenolic compounds' identification was achieved by the absorbance recorded in the chromatograms relative to external standards. Standards used included gallic acid, 
benzoic acid, catechin, caffeic acid and ferulic acid. The data were further quantified by ChemStation software B 01 03 (Agilent Technologies).

\section{Results and discussion}

Production of total phenolic compounds under different culture conditions

In an earlier study conducted by Rapta et al. (2005) increased free radical scavenging and antioxidant activities of metabolites (carotenoids) produced by yeasts under heavy metal stress was reported. However, it is important to know whether only carotenoids are responsible for this increase or some other metabolites, particularly phenolic compounds are also involved. As phenolic compounds are well known for their antioxidant activities, in the present investigation total phenolic contents (TPC) of $R$. glutinis were determined directly on the "cells" as well as from the "extracts". To the best of our knowledge, this is the first report of occurrence of phenolic compounds in yeasts, particularly in the investigated species.

The extracts of $R$. glutinis cells were prepared in DMSO to observe the effect of stress factors on phenolic contents and antioxidant activities. Under control culture conditions with no medium supplementation with stress factors, TPC produced by $R$. glutinis were 30.8 and $37.69 \mathrm{mg} \mathrm{GAE} \mathrm{g}^{-1}$ in "cells" and "extracts", respectively. A substantial increase in TPC was observed when $R$. glutinis was grown under non-lethal and maximally tolerated concentration of either $\mathrm{NaCl}(1-5 \%)$ or $\mathrm{H}_{2} \mathrm{O}_{2}(1-5 \mathrm{mM})$ on basal media. The phenolic contents as determined directly on the "cells" ranged from 38.22 to $62.72 \mathrm{mg} \mathrm{GAE} \mathrm{g}^{-1}$ in cultures stressed with different molar concentrations of $\mathrm{H}_{2} \mathrm{O}_{2}$ compared to control (30.8 $\mathrm{mg} \mathrm{GAE} \mathrm{g}^{-1}$ ). However, it ranged from 18.92 to $40.45 \mathrm{mg} \mathrm{GAE} \mathrm{g}^{-1}$ in cultures stressed with different concentrations of $\mathrm{NaCl}$ (Table 1). On the contrary, the phenolic contents from "extracts" ranged from 34.94 to $47.49 \mathrm{mg} \mathrm{GAE} \mathrm{g}^{-1}$ in $\mathrm{NaCl}$-stressed cultures whereas it ranged from 29.04 to $50.15 \mathrm{mg} \mathrm{GAE} \mathrm{g}^{-1}$ in $\mathrm{H}_{2} \mathrm{O}_{2}$-stressed cultures (Table 1). The highest levels of TPC were observed in $4 \mathrm{mM} \mathrm{H} \mathrm{H}_{2} \mathrm{O}_{2} \quad\left(50.15 \mathrm{mg} \mathrm{GAE} \mathrm{g}^{-1}\right)$ and $1 \% \mathrm{NaCl}$ (47.49 $\mathrm{mg} \mathrm{GAE}^{-1}$ ) -stressed cultures compared to control (37.69 $\mathrm{mg} \mathrm{GAE} \mathrm{g}^{-1}$ ). The increase in phenolic contents in $R$. glutinis reflects operation of some defence mechanism under stress.

\section{Radical scavenging capacities}

The results of RSC estimations are strongly dependent on the testing system. No single method can assure the complete examination of antioxidant capacity in the samples
Table 1 Total phenolic content of cells and cell free DMSO extracts of Rhodotorula glutinis grown under stress of $\mathrm{NaCl}$ or $\mathrm{H}_{2} \mathrm{O}_{2}$

\begin{tabular}{lll}
\hline Stress factor & \multicolumn{2}{l}{ Total phenolic contents $\left(\mathrm{GAE} \mathrm{mg} \mathrm{g}{ }^{-1}\right) \mathrm{DCW}$} \\
\cline { 2 - 3 } & Cells & $\begin{array}{l}\text { Cell free DMSO } \\
\text { extracts }\end{array}$ \\
\hline Control & 30.80 & 37.69 \\
$1 \% \mathrm{NaCl}$ & 30.06 & 47.49 \\
$2 \% \mathrm{NaCl}$ & 18.92 & 38.26 \\
$3 \% \mathrm{NaCl}$ & 40.45 & 34.94 \\
$4 \% \mathrm{NaCl}$ & 24.86 & 46.15 \\
$5 \% \mathrm{NaCl}$ & 40.45 & 40.37 \\
$1 \mathrm{mM} \mathrm{H} \mathrm{O}_{2}$ & 62.72 & 44.29 \\
$2 \mathrm{mM} \mathrm{H} \mathrm{O}_{2}$ & 50.84 & 34.60 \\
$3 \mathrm{mM} \mathrm{H} \mathrm{O}_{2}$ & 38.22 & 33.65 \\
$4 \mathrm{mM} \mathrm{H}_{2} \mathrm{O}_{2}$ & 54.55 & 50.15 \\
$5 \mathrm{mM} \mathrm{H}_{2} \mathrm{O}_{2}$ & 43.42 & 29.04 \\
\hline
\end{tabular}

under investigation. Antioxidant activity may be more reliably assessed by a combination of several tests and assays. In the present study, RSC of extracts was determined using ABTS, DPPH and EPR spin-trapping techniques and correlated with TPC. While ABTS and DPPH tests were used to determine total antioxidant activity, EPR spin-trapping technique was applied to investigate the ability of various DMSO extracts to scavenge the reactive radicals.

Total antioxidant activity measured by ABTS and DPPH assays were evaluated for extracts obtained from stressed $R$. glutinis and compared with the control. The antioxidant activity established by ABTS test was found to be the highest in culture extracts stressed with $4 \mathrm{mM} \mathrm{H}_{2} \mathrm{O}_{2}$ $\left(1.4 \mu \mathrm{M} \mathrm{TEAC}^{-1}\right)$ and $4 \% \mathrm{NaCl}\left(1.1 \mu \mathrm{M} \mathrm{TEAC}^{-1}\right)$ as compared to control samples $\left(0.4 \mu \mathrm{M} \mathrm{TEAC}^{-1}\right)$ (Fig. 1a). Similarly, the total antioxidant capacity as determined by DPPH test was also the highest in cultures stressed with $4 \% \mathrm{NaCl}\left(1.8 \mu \mathrm{M} \mathrm{TEAC} \mathrm{g}^{-1}\right)$ and $4 \mathrm{mM}$ $\mathrm{H}_{2} \mathrm{O}_{2} \quad\left(1.8 \mu \mathrm{M}\right.$ TEAC g $\left.{ }^{-1}\right)$ compared to control $\left(0.5 \mu \mathrm{M} \mathrm{TEAC} \mathrm{g}^{-1}\right)$ (Fig. 1b). A significant correlation was obtained between total phenolic content vs. ABTS $\left(R^{2}=0.9237\right)$ and DPPH $\left(R^{2}=0.9586\right)$ considering the values of $2-5 \mathrm{mM} \mathrm{H}_{2} \mathrm{O}_{2}$. Similarly, a good correlation (the correlation coefficient $R^{2}=0.8784$ ) was observed between ABTS and DPPH tests. It provides strong evidence that the predominant source of antioxidant activity derives probably from phenolic compounds in yeasts. However, no correlation was observed between phenolic contents from $\mathrm{NaCl}$-stressed cultures and ABTS/DPPH tests. This inconsistency might be due to a change in phenolic profile during cultivation under osmotic stress, for example carotenoids as reported previously (Edge et al. 1997; Marova et al. 2004) might contribute considerably to the antioxidant activity. As stated earlier, stress in biological 

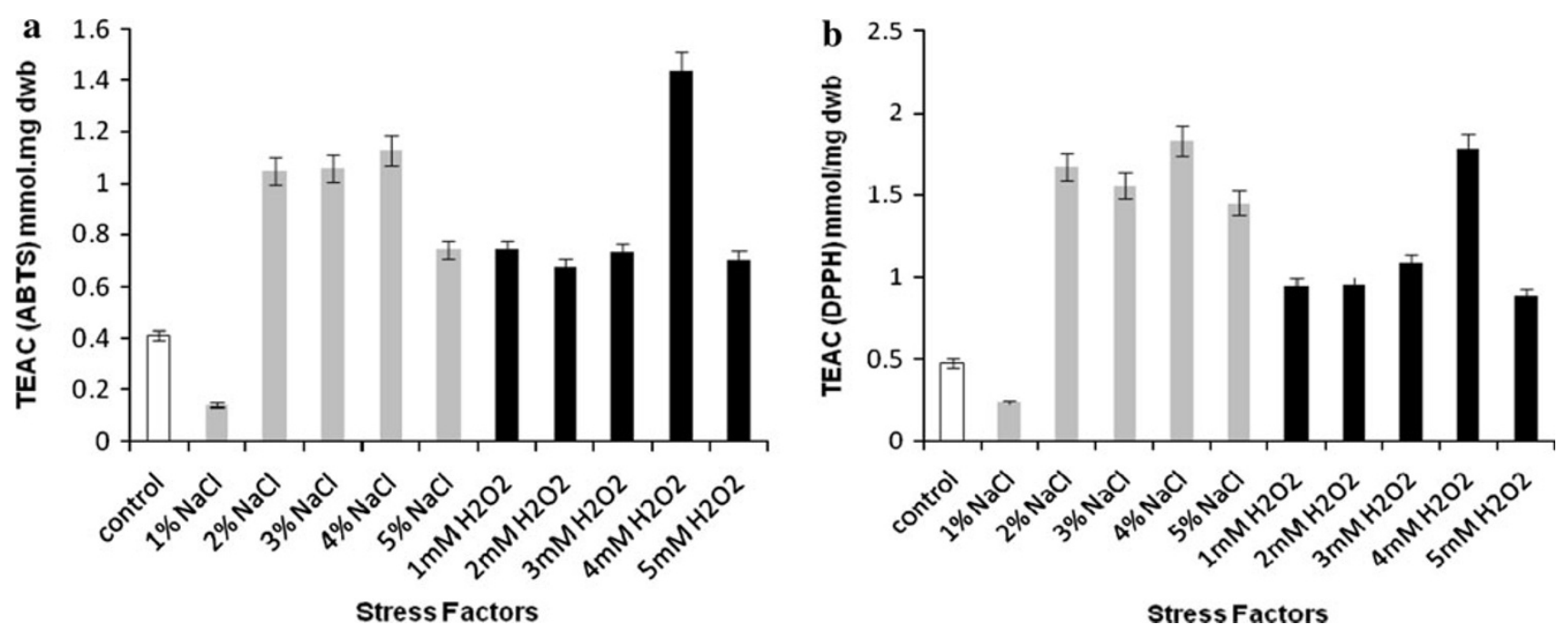

Fig. 1 Trolox equivalent antioxidant capacity of DMSO extracts of $R$. glutinis as determined by a ABTS assay and $\mathbf{b}$ DPPH assay

systems might induce the formation of new metabolites or change the behaviour of organisms under stress. Our results are in conformity with Rapta et al. (2005) who also reported an increased level of total antioxidant capacity of $R$. glutinis stressed with heavy metal ions $\mathrm{Ni}$ (II) and $\mathrm{Zn}$ (II).

The characteristic experimental EPR spectrum of ${ }^{\circ} \mathrm{DMPO}$ $\mathrm{SO}_{4}{ }^{-}$spin adduct recorded during the thermally initiated decomposition of $\mathrm{K}_{2} \mathrm{~S}_{2} \mathrm{O}_{8}$ in DMSO at $333 \mathrm{~K}$, along with its simulation $\left(a_{\mathrm{N}}=1.296 \mathrm{mT}, a_{\mathrm{H}}^{\beta}=0.938 \mathrm{mT}, a_{\mathrm{H}}^{\gamma}=0.139\right.$ mT; $g=2.0059$ ) are shown in Fig. 2a. Figure 2b represents the original sets of 20 individual EPR spectra monitored in the presence of DMPO during heating of $\mathrm{K}_{2} \mathrm{~S}_{2} \mathrm{O}_{8}$ at $333 \mathrm{~K}$ for the reference sample DMSO (200 $\mu \mathrm{L}$ DMSO, $25 \mu \mathrm{L} 0.2 \mathrm{M}$ DMPO in DMSO, $25 \mu \mathrm{L} 0.01 \mathrm{M} \mathrm{K}_{2} \mathrm{~S}_{2} \mathrm{O}_{8}$ in DMSO) and for DMSO extracts of $R$. glutinis grown under stress of either $\mathrm{NaCl}$ or $\mathrm{H}_{2} \mathrm{O}_{2}(200 \mu \mathrm{l}$ extract in DMSO, instead of DMSO in reference sample). It should be noted here that the decrease in the directly monitored EPR signal intensity of spin adducts is influenced by the concentration of individual extracts (Fig. 2b). Figure 3 shows a time dependence of EPR integral intensities (evaluated by double integration of sets of 20 individual EPR spectra for each measurement, e.g. Fig. 2b) representatively for the extracts of $R$. glutinis. The EPR integral intensity after $22 \mathrm{~min}$ detected for the extracts was compared to that of the reference. The difference between these EPR intensities is proportional to the amount of radicals terminated by the scavengers present in the investigated extract sample (Fig. 3), and is called relative radical scavenging capacity (RRSC, expressed in \%). Finally, RRSC values were recalculated to the TEAC values (molar amount of trolox $/ 1 \mathrm{~g}$ of dry extract inducing the identical changes in RRSC) using calibration curve obtained under strictly identical conditions for trolox solutions in $\mathrm{K}_{2} \mathrm{~S}_{2} \mathrm{O}_{8} / \mathrm{DMPO} / \mathrm{DMSO}$ systems.
The radical scavenging ability from EPR spin-trapping assay of $\mathrm{H}_{2} \mathrm{O}_{2}$-stressed cultures ranged from 38.6 to $56.1 \mu \mathrm{mol}$ trolox $\mathrm{g}^{-1}$ with the highest in $1 \mathrm{mM} \mathrm{H}_{2} \mathrm{O}_{2}$ $\left(56.1 \mu\right.$ mol TEAC $\left.\mathrm{g}^{-1}\right)$. Whereas in $\mathrm{NaCl}$-stressed cultures, it ranged from 35.8 to $44.6 \mu \mathrm{M}$ TEAC $\mathrm{g}^{-1}$ with the highest in $5 \% \mathrm{NaCl}\left(44.6 \mu \mathrm{M}\right.$ TEAC g $\left.{ }^{-1}\right)$ as compared to

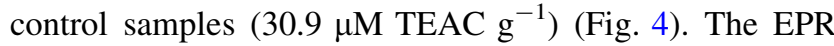
spin-trapping and ABTS/DPPH spectrophotometric results are not correlated. This may be explained due to operation of different mechanism of action in the tests used, as most probably distinct reaction pathways are involved in the termination of a stable DPPH and $\mathrm{ABTS}^{\bullet+}$ radical species and the reactive $\mathrm{SO}_{4}^{\circ-}$ radical anion (Zalibera et al. 2009) by active compounds present in the investigated samples. In EPR experiments, we generate the $\mathrm{SO}_{4}^{\circ-}$ with high redox potential, which are capable to react with a variety of organic compounds present in the extracts (e.g. glucan, polysaccharides and carotenoids) other than phenolics. Whereas in DPPH and ABTS assays, the dominating compounds scavenging radical species are $\mathrm{H}$-donor antioxidants. However, in general it was observed that extracts of cultures grown under stress showed higher radical scavenging ability than unstressed cultures. Overall, there was a significant increase in phenolic content and RSC of $R$. glutinis when stressed with $\mathrm{NaCl}$ or $\mathrm{H}_{2} \mathrm{O}_{2}$. This is a first report of occurrence of phenolic compounds in $R$. glutinis.

HPLC determination of phenolic compounds

The DMSO extracts of $R$. glutinis were evaluated using HPLC. Preliminary studies with mobile phase of acetonitrile and acidified water with acetic acid $(\mathrm{pH} 2.8)$ were conducted. The phenolic compounds were detected at $272 \mathrm{~nm}$. All the samples reported positive for various 
Fig. 2 a Experimental (full line) and simulated (dotted line) EPR spectrum $(\mathrm{SW}=6 \mathrm{mT})$ of ${ }^{-} \mathrm{DMPO}-\mathrm{SO}_{4}{ }^{-}$spin adduct recorded during the thermally initiated decomposition of $\mathrm{K}_{2} \mathrm{~S}_{2} \mathrm{O}_{8}$ in DMSO at $333 \mathrm{~K}$. Simulation spin Hamiltonian parameters: $a_{\mathrm{N}}=1.296 \mathrm{mT}$, $a_{\mathrm{H}}^{\beta}=0.938 \mathrm{mT}$,

$a_{\mathrm{H}}^{\gamma}=0.139 \mathrm{mT} ; g=2.0059$.

b Time course of 20 individual EPR spectra obtained for samples of DMSO extracts of $\mathrm{NaCl}$ and $\mathrm{H}_{2} \mathrm{O}_{2}$-stressed Rhodotorula glutinis CCY 20-226. All sets of 20 EPR spectra of DMPO adducts monitored during the thermal $(333 \mathrm{~K})$ decomposition of $\mathrm{K}_{2} \mathrm{~S}_{2} \mathrm{O}_{8}$ in the presence of DMSO extracts were taken for 22 min under the same experimental conditions as for reference sample (DMSO, instead of DMSO extracts). Extracts concentrations ( $\left.\mu \mathrm{g} \mathrm{mL}^{-1}\right)$ : control (257), $4 \%$ $\mathrm{NaCl}$ (115), $1 \mathrm{mM} \mathrm{H} \mathrm{O}_{2}$ (207), $2 \mathrm{mM} \mathrm{H}_{2} \mathrm{O}_{2}$ (207), $4 \mathrm{mM} \mathrm{H} \mathrm{O}_{2}$ (131) and $5 \mathrm{mM} \mathrm{H}_{2} \mathrm{O}_{2}$ (216)

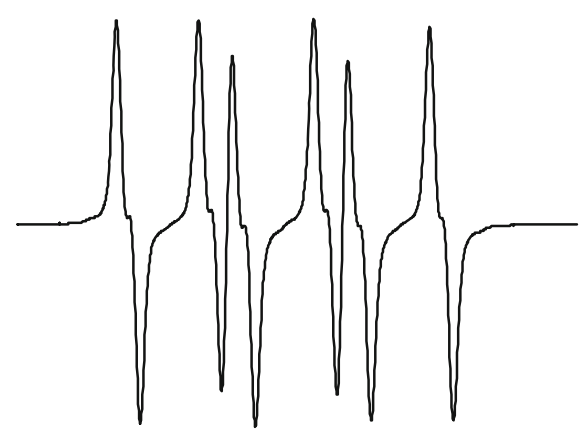

$\mathbf{a}$
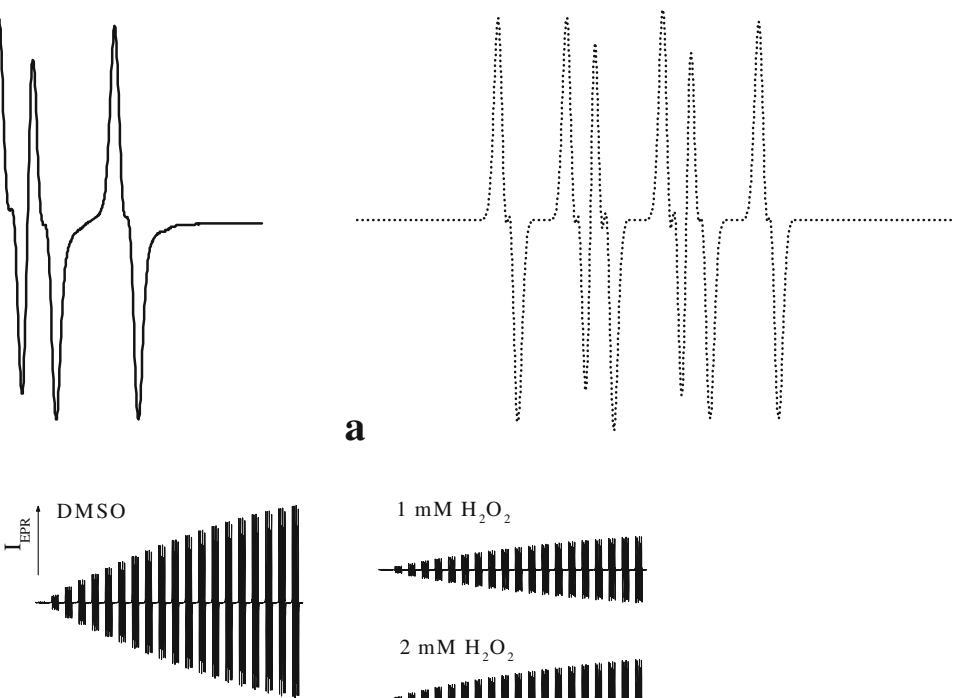

$1 \mathrm{mM} \mathrm{H}_{2} \mathrm{O}_{2}$

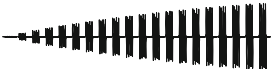

$2 \mathrm{mM} \mathrm{H}_{2} \mathrm{O}_{2}$

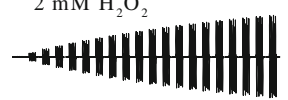

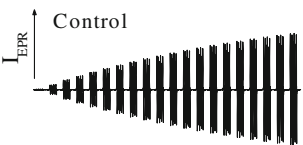
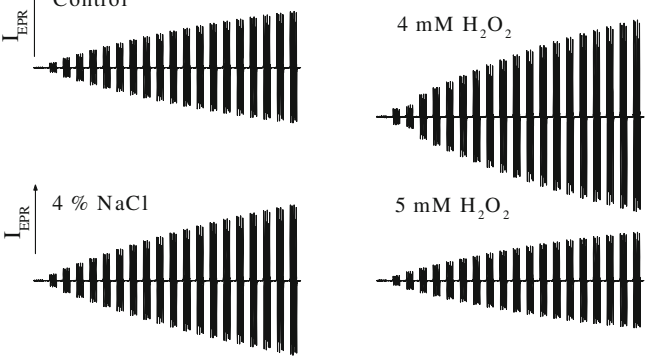

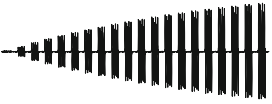

b

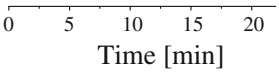

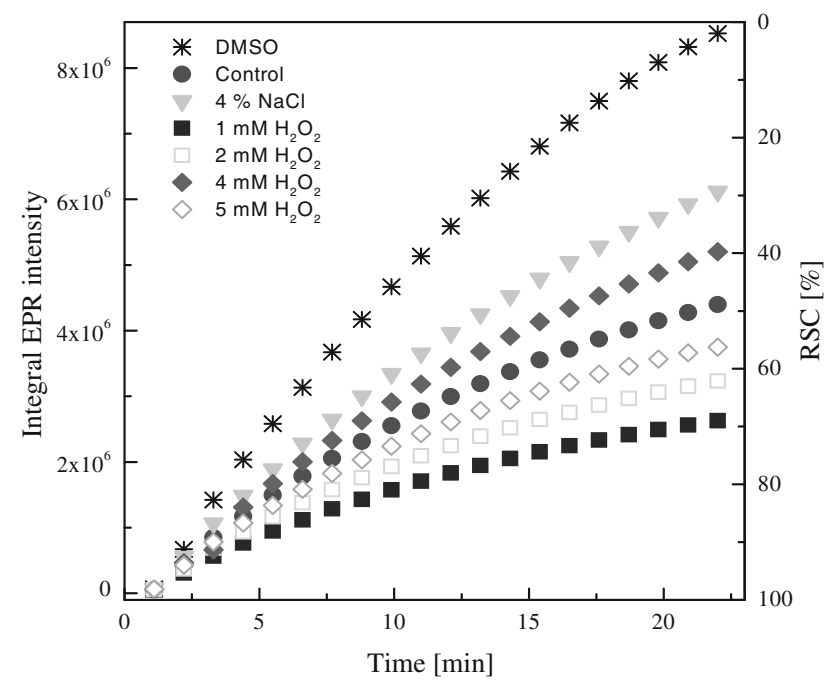

Fig. 3 Time course of EPR integral intensities of DMPO adducts (spectra shown in Fig. 2b) recorded during first $22 \mathrm{~min}$ of the thermal decomposition of $\mathrm{K}_{2} \mathrm{~S}_{2} \mathrm{O}_{8}$ in the presence of DMSO extracts of R. glutinis grown under stress of $\mathrm{NaCl}$ or $\mathrm{H}_{2} \mathrm{O}_{2}$

phenolic compounds viz., gallic acid, benzoic acid, catechin, caffeic acid and ferulic acid in the experiential peaks (Fig. 5). It was observed that there is a metabolic shift in

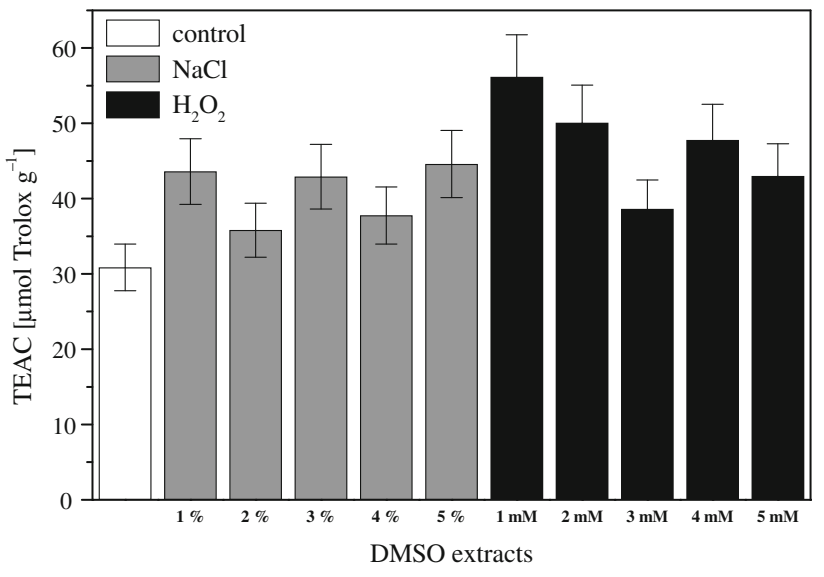

Fig. 4 Radical scavenging capacities (equated to actual dry weight of the samples) expressed as TEAC and evaluated by EPR spin trapping of DMSO extracts of $R$. glutinis grown under various concentrations of $\mathrm{NaCl}$ or $\mathrm{H}_{2} \mathrm{O}_{2}$

cultures when stressed with either $\mathrm{NaCl}$ or $\mathrm{H}_{2} \mathrm{O}_{2}$. Using HPLC, Rizzo et al. (2006) determined phenolics adsorbed on yeasts grown on different media. Phenolic compounds produced by sclerotia of the fungus Inonotus obliquus have 


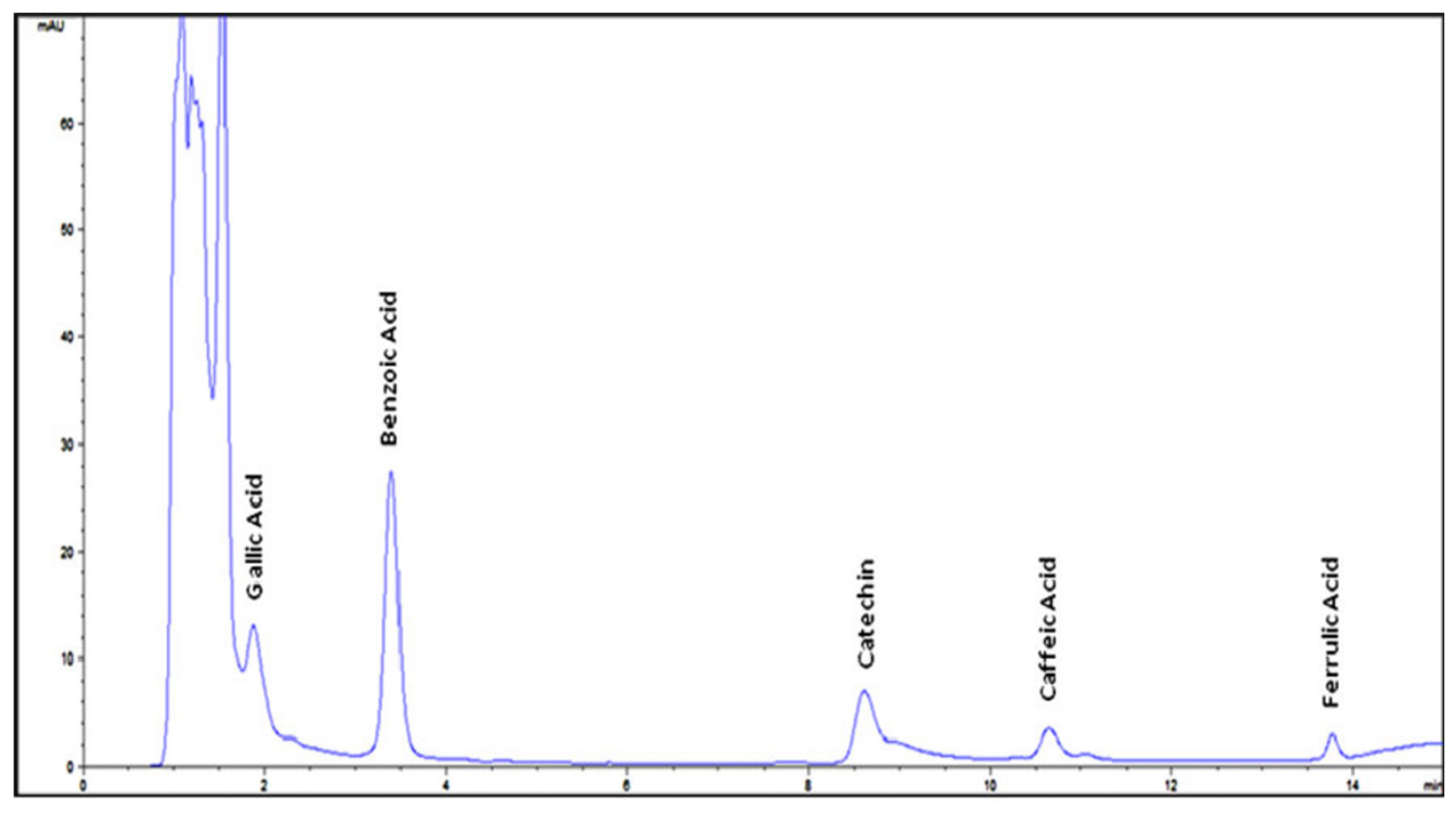

Time [min.]

Fig. 5 HPLC profile of the DMSO extracts of $R$. glutinis showing presence of various phenolic compounds at $272 \mathrm{~nm}$

been reported to be the active constituents responsible for antioxidant activities (Zheng et al. 2009). However, there is no report of occurrence of phenolics in yeasts. In the present investigation, extracts prepared from yeasts grown under stress of $\mathrm{H}_{2} \mathrm{O}_{2}$ or $\mathrm{NaCl}$ reported five peaks indicating a significant amount of phenolic compounds in the investigated species.

\section{Conclusions}

The results of the present study reported that $R$. glutinis when grown under stress of either $\mathrm{NaCl}$ or $\mathrm{H}_{2} \mathrm{O}_{2}$ resulted in an increased amount of total phenolic compounds. The results were further supported by the enhanced RSC of the extracts obtained from stressed cultures. A total of five phenolic compounds viz., gallic acid, benzoic acid, catechin, caffeic acid and ferulic acid were detected for the first time in R. glutinis. This investigation will further form a basis for the use of yeasts as a source of antioxidants and in formulation of functional foods and pharmaceutical preparation.

Acknowledgments The work was supported by grants VEGA No. 1/0747/08, No. 1/0018/09, No. 2/0005/10 and No. 1/0975/12 from the Grant Agency of Ministry of Education, Slovak Republic. RKS is also thankful to Slovak Academic Information Agency (SAIA) for awarding scholarship under National Scholarship Programme of the Slovak Republic.

Open Access This article is distributed under the terms of the Creative Commons Attribution License which permits any use, distribution, and reproduction in any medium, provided the original author(s) and the source are credited.

\section{References}

Arts MJTJ, Haenen GRMM, Voss HP, Bast A (2004) Antioxidant capacity of reaction products limits the applicability of the trolox equivalent antioxidant capacity (TEAC) assay. Food Chem Toxicol 42:45-49

Bhosale P, Gadre RV (2001) Carotene production in sugarcane molasses by a Rhodotorula glutinis mutant. J Ind Microbiol Biotechnol 26:327-332

Certik M, Breierova E (2002) Adaptation responses of yeasts to environmental stress. Chem Listy 96:147

Chen LS, Ma Y, Chen LJ, Zhao CH, Maubois JL, Jiang TM, Li HM, He SH (2010) Antioxidant activity of two yeasts and their attenuation effect on 4-nitroquinoline 1-oxide induced in vitro lipid peroxidation. Int J Food Sci Technol 45:555-561

Daeschel M (2004) Live yeast in beer increases its antioxidant activity. Emerg Food Res Dev Rep 9:1

Edge R, McGarvey DJ, Truscott TG (1997) The carotenoids as antioxidants. J Photochem Photobiol B 41:189-200

Estruch F (2000) Stress controlled transcription factors, stress induced genes and stress tolerance in budding yeasts. FEMS Microbiol Rev 24:469-486

Greenwald P, Clifford CK, Miner JA (2001) Diet and cancer prevention. Eur J Cancer 37:948-965

Halliwell B, Gutteridge JMC (1989) Free radicals in biology and medicine, 2nd edn. Japan Scientific Societies Press, Tokyo

Jaehrig SC, Rohn S, Kroh L, Wildenauer FX, Lisdat F, Fleischer LG, Kurz T (2008) Antioxidative activity of (1-3), (1-6)-b-d-glucan from Saccharomyces cerevisiae grown on different media. LWT Food Sci Technol 41:868-877

Kullisaar T, Zilmer M, Mikelsaar M, Vihalemm T, Annuk H, Kairane C, Kilk A (2002) Two antioxidative lactobacilli strains as promising probiotics. Int J Food Microbiol 72:215-224

Kumura H, Tanoue Y, Tsukahara M, Tanaka T, Shimazaki K (2004) Screening of dairy yeast strains for probiotic applications. J Dairy Sci 87:4050-4056

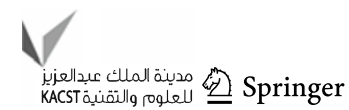


Marova I, Breierova E, Koci R, Friedl Z, Slovak B, Pokorna J (2004) Influence of exogenous stress factors on production of carotenoids by some strains of cartenogenic yeasts. Ann Microbiol 54:73-85

Miquel J, Romano-Bosca A (2004) Oxidative stress and antioxidant diet supplementation in ageing, arterosclerotic and immune dysfunction processes. ARS Pharmacy 45(2):91-109

Psomas EI, Andrighetto C, Litopoulou-Tzanetaki E, Lombardi A, Tzanetakis N (2001) Some probiotic properties of yeast isolates from infant faeces and feta cheese. Int J Food Microbiol 69:125-133

Psomas EI, Fletouris DJ, Litopoulou-Tzanetaki E, Tzanetakis N (2003) Assimilation of cholesterol by yeast strains isolated from infant feces and feta cheese. J Dairy Sci 86:3416-3422

Ramotar D, Belanger E, Brodeur I, Masson JY, Drobetsky EA (1998) A yeast homologue of the human phosphotyrosyl phosphatase activator PTPA is implicated in protection against oxidative DNA damage induced by the model carcinogen 4-nitroquinoline1-oxide. J Biol Chem 273:21489-21496

Rapta P, Polovka M, Zalibera M, Breierova E, Zitnanova I, Marova I, Certik M (2005) Scavenging and antioxidant properties of compounds synthesized by cartenogenic yeasts stressed by heavy metals-EPR spin trapping study. Biophy Chem 116:1-9

Re R, Pellegrini N, Proteggente A, Pannala A, Yang M, Rice-Evans C (1999) Antioxidant activity applying an improved ABTS radical cation decolorization assay. Free Rad Biol Med 26:1231-1237
Rizzo M, Ventrice D, Varone MA, Sidari R, Caridi A (2006) HPLC determination of phenolics adsorbed on yeasts. J Pharm Biomed Sci 42:46-55

Scalbert A, Williamson G (2000) Dietary intake and bioavailability of polyphenols. J Nutr 130:2073-2085

Wardman P (1989) Reduction potentials of one-electron couples involving free-radicals in aqueous-solution. J Phys Chem Ref Data 18:1637-1755

Wouters JTM, Ayad EHE, Hugenholtz J, Smit G (2002) Microbes from raw milk for fermented dairy products. Int Dairy $\mathbf{J}$ 12:91-109

Yen GC, Chen HY (1995) Antioxidant activity of various tea extracts in relation to their mutagenicity. J Agric Food Chem 43:27-32

Yu L, Haley S, Perret J, Harris M (2004) Comparison of wheat flours grown at different locations for their antioxidant properties. Food Chem 86:11-16

Zalibera M, Rapta P, Staško A, Brindzová L, Brezová V (2009) Thermal generation of stable $\mathrm{SO}_{4}^{--}$spin trap adducts with superhyperfine structure in their EPR spectra: an alternative EPR spin trapping assay for radical scavenging capacity determination in dimethylsulphoxide. Free Rad Res 43:457-469

Zheng W, Zhang M, Zhao Y, Wang Y, Miao K, Wei Z (2009) Accumulation of antioxidant phenolic constituents in submerged cultures of Inonotus obliquus. Biores Technol 100:1327-1335 